\begin{tabular}{|c|c|}
\hline \multirow{3}{*}{ 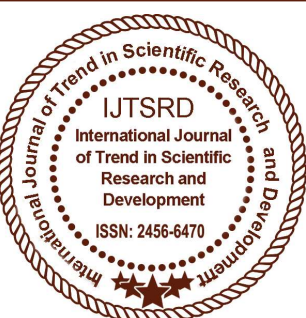 } & $\begin{array}{l}\text { International Journal of Trend in Scientific } \\
\text { Research and Development (IJTSRD) }\end{array}$ \\
\hline & Access Journal \\
\hline & ISSN No: 2456 - 6470 | www.ijtsrd.com | Volume - 2 | Issue -3 \\
\hline
\end{tabular}

\title{
Masculinity versus Femininity: An Analysis of Woman at Point Zero written by Nawal El Saadawi
}

\author{
Thinley Wangmo \\ Masters of Arts in English, \\ Lovely Professional University, \\ Punjab, India
}

\author{
Ms. Priyanka Sharma (Advisor) \\ Assistant Professor, Department of English, \\ Lovely Professional University, \\ Punjab, India
}

\section{ABSTRACT}

Masculinity versus femininity is regarded as "tough versus gentle" culture. Femininity is considered to be the collection of qualities or nature of the female sex. It is closely connected with softness, submissiveness, being emotional, and weak. Masculinity is considered to be the feature of male sex. It is linked to being strong, and hard. The categorization of superiority of masculinity and inferiority of femininity is dominant worldwide. Femininity and masculinity are social identities which have created waves of imbalance and destruction in human lives. It breeds violence, injustice, loss of moral values, and human ruin. It sets out to trap into which many people fall. The source of Feminism germinates in women's quest to achieve equality and justice between the sexes and to solve the gendered conflict.

This research paper endeavors to employ the feminist approach to analyze the presence of masculinity versus femininity in Woman at Point Zero by Nawal El Saadawi. It attempts to expose the destructive influence attached to the term masculinity and femininity which finds its outlet through human behavior and actions. It aims to examine how men bring the downfall of women through the assertion of their masculine trait which is deeply rooted in them. The study also aims to analyze how women also contribute in bringing their own downfall. It also attempts to reveal how women try to combat male domination in their pursuit of self-identity and liberation. This research paper fervently aims to espouse for equality and the harmony of coexistence between the two sexes to have human right for all.
Keywords: Superior, inferior, oppression,
masculinity, femininity, equality

\section{INTRODUCTION}

Nawal El Saadawi, is an internationally known figure. She is known to be called as "Simone De Beauvoir" to Arab world. The novel Woman at Point Zero identifies the causes of women's abysmal plight. Nawal El Saadawi is the author as well as the narrator in her novel Woman at Point Zero. The novel commences with the author Saadawi introducing the readers to the events which had led to the imprisonment of her protagonist Firdaus in the novel. The shift in the role of narration occurs after the writer Saadawi meets her protagonist Firdaus, who is a prisoner then narrates her compelling story to the author. Woman at Point Zero portrays the prominent issues of suppression of women, female circumcision, self-alienation, struggle between masculinity and femininity and regaining of self-identity of women. Saadawi depicts oppression of women through the leading protagonist Firdaus and her struggle in out shadowing the masculine domination. Nawal El presents woman's life which is fractured and dictated by events outside of her control. She presents her leading character being aware of her deplorable plight and trying to rise above her experiences into way of knowing herself and the world.

Feminism is an overriding element in Saadawi's Woman at Point Zero. The theoretical background of Feminism not only deals with women but it 
encompasses an entire history behind its development. The First Wave of Feminism addressed issues like suffrage and property rights. Mary Wollstonecraft wrote her first feminist treatise $A$ Vindication of the Right of Woman (1792) which was one of the earliest projection of the First Wave of Feminism which is still revered as a seminal text. She wrote how women are not inferior to men and how they should be treated equally. She highlighted how women appear inferior only because they lack education. Virginia Woolf's $A$ Room of One's Own (1929) mentioned the hurdle that female writers encounter as the men dominate the world with their ideology of supremacy.

Simone de Beauvoir started Feminism in The Second Sex (1949) and it gained its momentum in the 1960s.De Beauvoir with vigor projected the inhuman gender division which reduces women to the inferior level. Simone de Beauvoir in her book The Second Sex famously wrote, "One is not born, but rather becomes, woman" (330). Beauvoir asserts how gender is constructed. She lucidly highlights how under the cultural compulsion one "becomes a woman". The Second Wave of Feminism delved into issues like domestic violence, solidarity, sexuality, the workplace and reproductive rights. The Third Wave of Feminism refers to the chain of feminist activities which continues seeking true liberation. It addresses issues like violence against women, trafficking, body surgery, self-mutilation and endless plight of women. The movement strives to address the women's issue and to find solution to gender disparity. The feminist writers have sought out literature to raise awareness of the gender problem and to redeem women to their rightful position which was deprived ever since the dawn of civilization. The imprisonment of women and their unjust status are questioned and the long silence is broken by women writers in the mid-sixties.

Jane Austen's Pride and Prejudice is a quintessential feminist literature. Elizabeth Bennett, one of the most loved female character follows her own path in spite of the rigid societal pressure to lead a married life which was expected for all women. She was known for her witty dialogue expressing her personal views. Feminist writers endeavor to attain the liberation of women from the adverse imposition imposed through social, political and economic dependence.

The novel Woman at Point Zero by Nawal El has been the source of research for many research scholars. It has been researched using various approaches. Feminism is explored in Saadawi's novel through the perspective of the female narrator Firdaus. Gloria Ada Fwangyil in "Cradle to Grave: An Analysis of Female Oppression in Nawal El Saadawi's Woman at Point Zero" observes how women are oppressed and subjugated right from infancy, childhood and adulthood. Gloria examines how Firdaus was discriminated through male oppression throughout her life. She asserts the need of social and political transformation to give right and equality to women in the society.

Oyeh O. Otu in "Prostitution: The Economics of Sex and Power Dynamics in El Saadawi's Woman at

Point Zero" points out although prostitution is taken to be a revolt against men in seeking freedom, it is still an industry hugely controlled by men. Prostitution is said to be modern day slavery. Otu asserts how Firdaus is deluded with frustration in thinking prostitution as being free, and independent. Otu presents how men control the sex industry making women sexual objects for economic gain.

A lot has been discussed however, what has been lacking in criticism or the lack of research gap are how men bring the downfall of women and how women also contribute to their own down spiral in the course of the battle waged between masculinity and femininity.

The elements of struggle between masculinity and femininity are dominant in Woman at Point Zero written by Nawal El Saadawi. The novel presents a patriarchal society. The title of the novel Woman at Point Zero speaks volume about the abysmal state of woman. Nawal El shows how men exert their power and control over women asserting their supremacy. The protagonist Firdaus is a voiceless soul caught in a whirlpool of violence and abuse. Her life is darkened from her infancy to the life of adulthood as she is the victim of male's atrocities. Her dejected life whirls her around and abandons her at the face value of point zero pronouncing her state of insignificance in the midst of a male dominated world.

The men bringing the downfall of women can be seen through their assertion of supremacy and viewing women as an inferior object to be abused for sexual pleasure. It is evident through the exploitation of Firdaus by her uncle, her husband and other men whom she encountered. The women are expected to remain in the state of servitude. The destructive effect 
of embracing masculinity can be seen in the inhuman characteristic of the father who had lost sight of being caring and compassionate in his veneration for his absolute manhood. He was completely devoid of human compassion placing himself at the pedestal and asserting his sense of supremacy expecting obedience. The narration of the washing of her father's leg by her lifeless mother and Firdaus being taught by her father to wash his leg reveals the utmost display of supremacy of male over women. Firdaus mentioned how she saw herself taking over what her mother used to do. The trend of slavish role is indoctrinated and made to be continued. Unhealthy social environment which streamline gender identity imposed on women by society is strongly reflected. Saadawi presents Firdaus's father emulating the typical characteristic of a masculine man to the extent that she fails to recognize him as her father.

The preference of male child over female child is highlighted through Firdaus's father who was indifferent to the death of female child but violent when the male child died venting out his anger by beating her mother. The social discrimination which commences right from infancy is elucidated towards female sex who are being viewed as insignificant and valueless. Firdaus's young playmate named Mohammadain acquaints her with the knowledge of sexuality at a premature age. His lifting up her clothes around her waist shows signs of burgeoning masculine trait being embedded in him through the societal influence which view women as the sexual object. Saadawi draws attention to the masculine traits being conditioned in a young boy by the society.

Firdaus mentions how her father knew how to get dowry in exchange of his virgin daughter. Saadawi presents how Firdaus is left at the mercy of her uncle who exercise his patriarchal power by marrying her to Sheik Mahmoud for dowry without getting her consent to clear his debt. Marriage was considered to be a kind of business in exchange of a virgin girl for dowry. The repercussions of such marriage leading to the consideration of women as personal property purchased through a trade, devaluing her and giving men the authorization to do what they please according to their whim is emphasized. The life of servitude as a wife is made evident with Firdaus' duties which encompasses of endless household chores leaving her with fatigue. Old Sheikh Mahmoud had deformity and was described in a revolting manner with pus oozing from his chin and his speech blemished with meanness who sees Firdaus as an object and a slave. Saadawi asserts marriage to be a kind of captivity, a tool where men expect absolute respect and obedience paralyzing women to being voiceless sex slaves in the form of wife deprived of emotion and aspirations.

Sheikh Mahmoud attacks Firdaus using sarcastic mocking masculine tone when she comes back to him after running away after his violent beating. He verbally assaults her asking why she has come back to him. He berates her and skins her with humiliating tone and accusing words annihilating her sense of self-worth. Firdaus and her mother are ill-treated by men as they were economically dependent on them. The implication of the world of master and slave, implication of woman as a slave is maintained through deprivation of women from economic equality. The abusive trait of masculinity is also asserted when Bayoumi physically assaults Firdaus when she mentions of looking for a job. Saadawi in Woman at Point Zero presents how Firdaus's desire of having a job is taken to be a tremendous violation and ousting of Bayoumi's manhood who becomes extremely violent and starts assaulting her verbally, physically and sexually. The men holding on to economic power is made evident in the novel. He even sends his friend to abuse her sexually treating her like a piece of dirt.

Virginia Woolf known for her book A Room of One's Own mentioned that the problems women face can be removed only when women attain social and economic equality with men. She was passionate about having a balance between man's self-realization and female's annihilation of self. Saadawi exposes how veneration for socially created masculinity leads to women annihilating themselves and losing their sense of worth. She poignantly reveals Firdaus's selfannihilation as she was always found placing the men in the foremost importance in her life. She was living in the dark shadow of the men in her life and was giving preference to men ignoring her inner self as she was conditioned to be unimportant. Firdaus is taught to show reverence for men abandoning her wants and desires.

Men are found making all the main choices. The freedom of making choice was completely unknown to women. Education was considered to be the field for men and no place for girls. The gendered constructed belief is shown making education only men's arena. Education was considered to be strongly 
prohibited to women's domain. It was a tool used by men to suppress women and to keep them under their control. Saadawi also shows how the societies exploit religious teaching to restrict women from receiving education. Firdaus's uncle mentions how it is totally unthinkable to send her to university as she will be sitting with men. He considers himself to be a respected Sheikh man who is incapable of allowing his niece to mix in the company of men. Saadawi sheds light on how women's education and economic soundness are means of freedom from the masculine yoke.

Firdaus mentions that her profession which is prostitution has been invented by men who are in control of the world. Marzouk, the dangerous pimp declares in a triumphant fashion saying, "I am in business. My capital is women's bodies and I don't mix work and love together" (126).Firdaus reveals the double standard of men who expect women to be virtuous but continues to exploit them making them stumble to the lowest point. She also reveals the hypocrisy of men who condemn the profession of prostitution yet expect high moral from women when they engage in the same act themselves. In her encounter with an Arab prince she declares "I am not a prostitute. But right from my early days my father, my uncle, my husband, all of them, taught me to grow up as a prostitute" (135).

Saadawi also presents how men cannot accept rejection from women which is taken to be an insult to their manhood. Firdaus's rejection of a very important personality from a foreign state makes him more ardent in pursuing her showing men's ungracious sense of self-regard for themselves over women. Firdaus even gets sent to jail for rejecting one of those important men which reveals political factor suppressing women. Saadawi also exposes the men's exploitation of women prostitute as a part of diplomatic tools and men's control over politics victimizing women. Saadawi traces the chivalrous roles played by men where Firdaus mentions how she abhorred those men who told her that they wanted to rescue her from the life she was leading. The entrapment tools devised by men over women that is the belief that women ought to be protected by men are disclosed. The highest sense of the evilness embedded in masculine spirit is found in dangerous pimp Marzouk who forcefully imposes his protection over Firdaus declaring there isn't a woman on the face of the earth who can protect herself. He declares "For me the word impossible does not exist" (127).
Marzouk exercises his power over Firdaus insisting on sharing in her earning and in fact confiscating the larger part for himself. He declares himself to be the master over Firdaus. She was unable to dodge his menacing control over her as her pimp as he had better connection with police than her. Saadawi also elucidates how law condemns women but turn blind eye to men's crime.

Self-empowerment and self-liberation are to be achieved only when one confronts with the ugly truth no matter how gross and humiliating it may be. Women also play their part in their downfall. Women causing the downfall of women are reflected through Firdaus's mother conducting clitoridectomy on her which leads to her crying all night. Saadawi condemns the act meted out by women who have actually gone through the same painful primitive torture which is promoted by traditional customs. Firdaus in her innocence refers to the female clitoris as "a piece of flesh" (16) which get cut off reveals the extreme exploitation and how she had no authority of her own body and life. It crystallizes how a girl child is being robbed off the right to choose and how she is a voiceless soul. It also highlight the brutal aggression carried out against women's bodies and the sufferings of women. The brutal ritual is associated with society's fixation with virginity. Her sense of sensuality is being taken away from her and she is being numbed. She recounts how she had the pleasure sensation with Mohammadain, her playmate before the clitoridectomy. In the later phase of her life she tries to reach that sensation but it was in vain. Saadawi is sensitizing the society of its flaws and shortcoming to create awareness. The marked injustice of patriarchal society conditioning women to have lower expectation devoid of dreams and adventure is exposed through Firdaus's gendered experience which is instilled in her by her mother who shows her routine work which consisted of fetching water in a heavy earthenware jar and making rows of dung cakes. Firdaus states:

My mother no longer sent me to the fields. Before the sun had started to appear in the sky, she would nudge me in the shoulder with her fist so that I would awaken, pick up the earthen jar and go off to fill it with water. Once back, I would sweep under the animals and then make rows of dung cakes which I had left in the sun (Nawal El Saadawi, 17). 
Saadawi emphasizes the destructive impact of the assertion of gender constructed identity which has made women spiritless and lifeless and on the other hand made men devoid of moral values and basic human understanding. Her mother and her aunt's submissive and docile nature towards her father and uncle embed in her the wrong message which makes her susceptible to abuse without questioning. Their timidity towards men make Firdaus to conceive that men can do anything that they please. When her uncle touches her, although she is uneasy, she does not show her disgust because it doesn't occur to her to do. Saadawi also delves into the most destructive attributes of women who bring their own downfall by paying blind loyalty to the privileges of men in their ignorance and remaining in perpetual enslavement. Firdaus's mother is intimidated by her father, and her feelings are suppressed indicating the submissive side of femininity. Silence was considered to be women's virtue and submissiveness to be their embellishment. Her father frequently beats her mother using his masculine tool to silence her and to make her voiceless. Men privileging themselves can be seen through Firdaus's father who was so inhuman. He eats alone leaving Firdaus watching him as he devoured the food. Firdaus mentions that she was so hungry that she could not cry. Virginia Woolf in A Room of One's Own comments:

Why did men drink wine and woman water? Why was one sex so prosperous and the other so poor? ...a thousand questions at once suggested themselves. But one needed answers, not questions; and an answer was only to be had by consulting the learned and the unprejudiced (22).

Saadawi illuminates how women have been ruined through self-annihilation under the oppressive dominating cruelty of men. She asserts how men place themselves over women and reiterate their importance generation after generation robbing women from their sense of thoughts and the essence of their existence imprisoning women in hollowness and emptiness. Her aunts dislike of her leads to her being at the mercy of her savage husband furling her towards chain of misfortune and finally on to the streets. Her uncle's wife expresses strong hatred for Firdaus instead of uplifting her as a woman. She was not in the least supportive and never sympathized with Firdaus. She was not at all sensitive to the suffering of Firdaus and she fails miserably to the woman of her own sex. She contributes to the down spiral of Firdaus's tragic life. She was consistently instigating her husband to get rid of Firdaus complaining about the difficulties faced and remarking that Firdaus eats too much. She expresses strong disapproval and desperate desire to get rid of Firdaus. Her hatred culminates to Firdaus marrying Sheik Mahmoud who was more than sixty years old when she had not yet turned nineteen.

Saadawi also presents how the elite woman ill-treats woman from lower status. Firdaus recounts how her uncle brought home a small maid who slept on the floor in her room. She mentions how one cold night she invited the maid to sleep with her on the bed. Her uncle's wife on seeing the maid sharing Firdaus's bed beats the maid as well as Firdaus. This substantiates how it is not only men who project women to be inferior suppressing them but also how women of the same sex look down at women because of their inferior status. Low class women are ill-treated by high class women just as all women are ill-treated by men. Firdaus was a bright student who dreamt of becoming a doctor, an engineer and a lawyer but unfortunately she becomes none.

The society's indifference to women's suffering is made explicit when Firdaus runs away from her husband after violent beating on the street with swollen eyes, and bruised face but no one pays attention to her. It was as if she was invisible to them. Saadawi's feminist empathy is obvious through her language and she portrays her fervent passion for advocating social justice for women's right. Firdaus upon reaching her uncle's house finds herself at loss of words when her aunt normalizes the beating as something natural and instead backfires her preaching about obedience and being a virtuous woman who remains tolerant by not complaining. Firdaus was being indoctrinated to be submissive and voiceless allowing men to abuse her at their whim. The gendered identity is being deeply and thoroughly entrenched in society's culture. It is embedded in people's action and belief that beating wife is completely natural.

The wealthy-looking woman named Sharifa instead of helping Firdaus takes advantage of her vulnerability when she finds Firdaus on the bank of the Nile. Although Sharifa seems to reveal how life had hardened her and admits that she is terribly hard, she makes no attempt to uplift Firdaus deplorable condition. She uses Firdaus to work for her by training her to be a high class prostitute exploiting her like all the other men she had met. She in the pretense 
of being motherly and sisterly crucifies Firdaus into never leaving the room day and night, only to be laying on the bed visited every hour by a man making money out of her.

Firdaus escapes the clutches of Sharifa and Fawzy only to meet a police man who positions to threaten her with an arrest and walks her through the dark alley to sexually abuse her. Firdaus in her endeavor to become a respectful woman finds herself a job in a company encountering Ibrahim, a fellow worker who was the head of a revolutionary committee within the company with whom she falls in love only to realize that he had been deceiving her proving him to be as exploitative as any other man. She becomes very hurt, betrayed and expresses her deep anguish declaring how hurt she was as she expected at least something from love.

Firdaus resorts to becoming prostitute from the hatred born against men. She states the time had finally arrived for her to "shed the last grain of virtue" (117) where she can no longer entertain herself with illusion. She believes that it is better to be "a successful prostitute rather than a misled saint (117) and all women are the prey of men's crafty ambition. Firdaus choice of embracing prostitution was a revolt against men as she asserts she had chosen this life of her own free will and freedom. She chooses prostitution as her rebellious act against authority exerted on her. It also reveals Firdaus's rejection of patriarchal imposition and taking power into her control. It also shows her revolt against men expecting high moral standards from women. It is also her way of turning men into sexual object, and refusing traditional standard.

Although Saadawi uses prostitution as Firdaus's weapon to rebel against men, she is very lucid in portraying prostitution as a violence inflicted by men against women. Prostitution is viewed to be a severe exploitation which propel rape, beating, and abuse. Pimp exercising their authority over their sex worker is made obvious with the ruthless pimp Marzouk. The harsh painful reality of prostitutes drowning themselves in deep psychological shame is showcased empathetically through Firdaus's scalding shame and turbulent turmoil. Saadawi projects female powerlessness, lack of education and opportunities to be the root causes of female prostitution which is a form of slavery in the modern world. She also shows the darkest tragedy of prostitution which robs woman off their sense of dignity. She emphasizes how woman being economically dependent on man leaves them at the mercy of man who pushes them to dire situation. She entreats and seeks elevation of women through education passionately to attain women's empowerment and liberation from the male domination. She values education as a freeing tool for women in freeing themselves from their own ignorance.

The assertion of feminist trait in Woman at Point Zero is made palpable in the preface of the novel. Nawal mentions Firdaus with her utmost reverence and describes her as someone who is unique and above other women. She was a woman who dared to challenge to overcome enslavement that deprive women of their access to opportunities, education and to real liberty. The title Woman at Point Zero Saadawi presents the presence of feminist element. Although zero denotes nothing at all; the point zero also denotes the beginning or a starting point of an origin. Saadawi in her masterful touches reveals how Firdaus fought against the waves of her struggle against nonentity to finding her inner source-her inner identity. One startling example of Firdaus's burgeoning feminist trait which emerged was when she was taken to Cairo after her parents' death by her uncle. She sees mirror for the first time and she mentions how looking at the mirror made her feel being born for the second time suggesting at that point in her story, she was totally shaped by society. She disliked what she saw in the mirror. The shift towards a more assertive and rebellious Firdaus is presented seeking her liberation.

Saadawi highlights turbulent journey of Firdaus of being inconsequential being to a person who is capable of claiming her identity and finding her liberation. Although her sense of liberation comes at the cost of her murdering the pimp Marzouk culminating to her death sentence. Her genuine sensation of liberation is truly found in telling the truth, even at the cost of her life. The protagonist's name Firdaus means "Paradise" which is the highest level. Her name "Firdaus" signifies her ways of liberating herself through the revelation of her truth which helps her to attain her level of paradise. Firdaus's absolute intolerance for female oppression, sexual violation and her utmost rejection of male supremacy is made transparent with her powerful statement which is haunting and brutal. She assertively mentions: "However, every single man I did get to know filled me with but one desire: to lift my hand and bring it smashing down on his face" (13-14).

Firdaus fleeing from a violent husband and marriage 
indicates her attempt in finding freedom away from enslavement of male domination and finding her own identity. It indicates that she is no longer willing to be abused by her husband. The more she was oppressed and subjugated, the more she was driven in seeking freedom. Saadawi's strong feminist sympathetic tone is very obvious when she mentions Firdaus being compelled into sleeping with a man in her utter dejected situation and coming in contact with a ten pound note. The note brings out overwhelming emotion of how money was always made an alien object which was out of her boundaries. The ten pound note induces in her a sense of unknown pleasure and power of being financially independent. A strong fierce realization endows in her as she reflects how money has always been made a forbidden object to her by her father, Sharifa, and her husband Sheikh Mahmoud. She gets the sensation of empowerment and freedom in having money of her own.

Saadawi depicts how women are kept in utter ignorance and darkness by men making them feel obligated to them by crippling women economically and keeping them handicapped. She asserts the economic empowerment which frees women from men's oppressive clutches. Her life as a prostitute is largely driven by her desire to seek independence where she owns her own body. She also considers prostitution less confining than the life of a female employee who becomes a prostitute as she is terrified of losing her job. Firdaus's realization that she is no longer free as a prostitute springs out when Marzouk, forcefully assert his control over her. She finds out that Marzouk has strong connection with police and realizes how he can easily play to his advantage making her see the idea of prostitution as being free as nothing but self-delusion. Her awakening to the fact that men control the sex industry leads to her making the decision to quit prostitution and to seek employment with her secondary certificate.

Marzouk, as usual with his infamous trait forbids her saying she has no authority to choose the type of work to do. He tries to subjugate her by beating her which leads to him being stabbed by her. Her stabbing Marzouk is a rejection of subjugation and exploitation showcased through self-defense. She felt triumphant and did not repent her action of killing him but instead she drew pride in herself as she had finally succeeded in scaring men. Saadawi also throws into light how men push women to extreme level leaving them with no choice but to strike back in a violent way. Firdaus mentions that she has liberated herself as she no longer fear life and death which enslaves her. She assertively with true feminist voice mentions she wants nothing and fears nothing making her free. Saadawi meticulously presents the assertion of feminist awakening in the woman character in her endeavor to achieve self-liberation from all oppression.

The protagonist of Woman at Point Zero crystalizes the strength, resilience and will power of the woman in the face of inhuman treatment vented against her. In the novel the leading character despite the extreme domination and victimization, she adamantly refused to remain victim to the oppressors. She struggled and brought up her long seasoned rebellious attributes which remained so passive breeding pus and pain longing for its outlet. Saadawi in her writing awakens the feminist consciousness of women and illuminates the realization of barriers and imposition which have limited the development of women in all sphere of lives. She depicts a strong character who gain a perspective of her true self who is not even afraid of death in her quest for self-discovery and selfempowerment.

\section{Conclusion}

The battle between masculinity and femininity had long begun and is still an incessant battle waged between the two sexes. The battle originates from the manipulation and distortion of masculinity being superior and femininity being deemed as inferior which breeds evil impulses. From examining the novel Woman at Point Zero, one can easily draw conclusion that there is no victory over the assertion of male being superior and female being considered as inferior as the outcomes are deprivation of human right, infliction of injustice and extreme deplorable behavior in the society based on flawed beliefs. It only leads to inhuman savage division and cycle of pain for women and abject moral deprivation in men. The men in their obsession to being masculine and in their blind reverence for supreme manhood become devoid of basic human values and emotion.

Both men and women are victims under the societal construction of gendered identity. The scenario of male glorification and demeaning of femininity leads to the burgeoning of an endless plight of women and inhuman behavioral from men. The indoctrination of gendered identity in the young child leads to the negative masculine trait in young boys who project violence and stifling self-alienation in young girls. Men become victims and prisoners of their own ego, 
hatred, and deception as they fear to let go of their sense of supremacy over women although they are very much aware of their wrong doings in the inner realm of their guilty turbulent conscience. Men need to unleash their fanatic obsession of superiority over women and on the other hand women need to dismantle their walls of servitude and self-isolation in seeking better enlightened world with fresh hopes and dreams.

Saadawi with her great insight and wisdom illuminates that it is not only men who are guilty of bringing the down spiral of women but how women also have their contributing factors in their cascading downfall sought through the acceptance of perpetual servitude, blind obedience and destructive selfannihilation. The failure of women characters towards each other is taken to be another destructive layer contributing to the wrecking of woman apart. The strong urgent need of women understanding the plight of one another and taking all measures in elevating each other through joint collaboration is hugely aspired and desired as a mean of combating against male's fierce domination. The strong unity and solid solidarity of women is passionately desired to combat men's unjust domination furled at women.

Self-reflection is considered to be very important as it is the process of looking inward as well as looking outward towards others which leads to the desired transformation. Saadawi examined the different levels of exploitations exercised by men which brings the tragic downfall of women. Women being vulnerable to all forms of exploitation are due to their unequal social status in term of religion, education, culture, politics and economic power. The women are kept in ignorance through endless limitations restricting them from venturing into the field of opportunities and possibilities. The economic dependence on men keep women extremely loyal with strong obligation towards men. Saadawi passionately demands the grace of benevolent education for women which will not only free them from the male dominated world but liberate them from their own ignorance which keeps them chained to life of abject exploitation.

Saadawi asserts how the idea of men being dominant over women are due to the result of societal manipulation based on their flawed beliefs and unjustified expectations from women. The hypocrisy of society is revealed through the values and virtues attached to a modest woman while man can escape being immoral and insensitive. Saadawi expresses the wonders of coexistence between men and women and the importance of giving equality to all in life to have harmony in the world. She expounds how the element of disharmony prevalent in the society between men and women can only subside when one stop asserting importance over the other and starts believing in the divine equality in all sphere of human lives.

Although the realm of universal patriarchy has lost the kind of credibility it once enjoyed its infamous presence is still pervasive which need to be addressed and given its due extermination for the elevation of humanity. One must always aspire for the life of equality between the two sexes, economic independence, political freedom, and social equality in their journey of life which should be sought, fought and revered by all those who believes in grace of liberating humanity. Saadawi's phenomenal book Woman at Point Zero presents the horrifying truth which still resonates in the present times making her novel truly phenomenal, overpowering, truly liberating and illuminating. Feminism is not only freeing for women but equally freeing of men from the captivity of patriarchy. One must understand that feminism is for all.

\section{Works Cited:}

1) Austen, Jane. Pride and Prejudice. London: Penguin, 1994.

2) Beauvoir, Simone De. The Second Sex. United States: Vintage, 1949.

3) Fwangyil, Gloria Ada. "Cradle to Grave:An Analysis of Female Oppression in Nawal El Saadawi's Woman at Point Zero." An International Journal of Language, Literature and Gender Studies, Vol.1, no1, 2012, pp .15-28.

4) Otu, Oyeh O. "Prostitution: The Economics of Sex and Power Dynamics in Nawal El Saadawi's Woman at Point Zero, Adimora- Ezeigbo's Trafficked and Ungiwe's On Black Sisters Street." World Journal of English Language, Vol.6,no 4 ,2016, pp. 8-15.

5) Saadawi, Nawal El. Woman at Point Zero. London: Zed Books, 2015.

6) Wallstonecraft, Mary. A Vindication of the Rights of Women. London: Penguin, 1792.

7) Woolf, Virginia. A Room of One's Own. 1929. Web. 20 November. 2017. 